\title{
CIDADE E DIREITOS SOCIAIS: CONFRONTO ENTRE O DIREITO FUNDAMENTAL À SAÚDE E OUTROS DIREITOS FUNDAMENTAIS NO CURSO DA PANDEMIA POR COVID-19
}

\author{
City and Social Rights: confrontation between the fundamental \\ rights to health and other fundamental rights in the course of the \\ pandemic phase by Covid-19
}

\section{Arícia Fernandes Correia}

Professora de Direito da Universidade do Estado do Rio de Janeiro. Pós-Doutorado em Direito Público pela Université Paris 1 - Panthéon-Sorbonne. Doutorado em Direito Público e Mestrado em Direito da Cidade pela UERJ. Membro Permanente do Fórum de Direito da Cidade da Escola da Magistratura TJ/RJ. Membro das Comissões de Direito Constitucional e Municipal da OAB/RJ (triênio 2019-2021) Procuradora do Município do Rio de Janeiro (RJ, Brasil).

\section{Tatiana Mota Pinheiro Marinho}

Residente Jurídica da Procuradoria Administrativa da Procuradoria Geral do Município do Rio de Janeiro (RJ, Brasil). Pesquisadora do Núcleo de Estudos, Pesquisas e Extensão em Direito da Cidade - NEPECUERJ.

\section{Gláucia Sayuri Takaoka}

Formada em Direito na Universidade Federal do Ceará. Mestranda em Direito da Cidade pela Universidade do Estado do Rio de Janeiro (RJ, Brasil). Bolsista CNPQ.

\section{Resumo}

Trata-se de análise acerca da relevância dos direitos fundamentais sociais no Estado Democrático de Direito, da primazia que o direito à saúde adquiriu, em tempos de pandemia por Covid-19, e da possível colisão com liberdades e outros direitos sociais, bem como do papel normativo e administrativo dos Municípios no que diz respeito ao combate ao coronavírus, no contexto federativo brasileiro e dos novos desafios de seu papel de "garante", não mais apenas da zeladoria da Cidade, mas, em relevante parte, do mínimo existencial "urbano"dos seus habitantes, no que diz respeito às competencias locais em matéria de saúde primaria, educação fundamental, assistência básica e moradia adequada. Cuidar-se-á também dos conflitos normativos entre Municípios e União, a fim de se verificar se a jurisprudência de exceção em razão da Covid-19, em torno da interpretação da Lei Federal n. 13.979/2020, serviu ao fortalecimento ou amesquinhamento da autonomia municipal e qual o resultado dessa equação. Paralelamente, cogitar-se-ão daqueles indivíduos que não puderam aderir às regras de prevenção ao contágio por Covid-19 justamente por não disporem de um mínimo existencial "urbano" que Iho permitissem, provando que, de fato, mais letal que o vírus SARS-COv-2 é a desigualdade social.

Palavras-chave: Colisão de direitos sociais. Mínimo existencial "urbano". Cidade e Pandemia. 


\section{Abstract}

It is an analysis about the origin of fundamental social rights in the Democratic Rule of Law, the primacy that the right to health acquired, in times of pandemic by Covid-19, and the possible collision with freedoms and other social rights, as well as the normative and administrative role of the Municipalities with regard to the fight against the coronavirus, in the Brazilian federative context and the new challenges of their role of "guarantee", no longer only of the janitorial of the City, but, in relevant part, of the "existential minimum urban" of its inhabitants, regarding to local competences in matters of primary health, basic education, basic assistance and adequate housing. It will also take care of the normative conflicts between Municipalities and the Union, in order to verify if the exceptional jurisprudence due to Covid-19, around the interpretation of Federal Law no. 13,979 / 2020, service to strengthen or weaken municipal autonomy and what is the result of this equation. At the same time, preference will be given to those who could not adhere to the rules of prevention of contagion by Covid-19 precisely because they do not have an existential "urban" minimum that would allow it, proving that, in fact, more lethal than the SARS virus - COv-2, is a social inequality.

Keywords: Collision of social rights. "Urban existential minimum". City and Pandemic.

\section{Sumário}

1. Os Direitos Sociais e a Constituição de 1988; 2. Os Direitos Sociais e a Cidade: "Mínimo Existencial Urbano"; 3. Cidade, Direito Social à Saúde e Pandemia por Covid-19; 3.1 Estado de emergência sanitária por Covid-19; 3.2 Competência concorrente dos entes estaduais e, suplementar, dos municipais; 3.3 Critérios de constitucionalidade balizadores das medidas restritivas a direitos; 4. Cidade e Desigualdade Social; 5. Notas; Referências.

\section{OS DIREITOS SOCIAIS E A CONSTITUIÇÃO DE 1988}

Habitar, trabalhar, locomover-se e se divertir: os lemas do planejamento urbano, segundo a Carta de Atenas, seriam habitação, transporte, trabalho e lazer. Era o Urbanismo batendo às portas da Modernidade, representado, por acaso, por direitos sociais, aqueles pertencentes à segunda geração dos direitos fundamentais, a demonstrar o quanto o planejamento da urbe nascera vocacionado para o usufruto coletivo de direitos à igualdade material.

Por outro lado, à Província, à Comuna, à Urbe, em seus primórdios, caberia essencialmente se restringir a ser apenas um braço político da Coroa para o exercício do poder local e, a princípio, para a zeladoria dos espaços comuns da cidade: cuidar de calçadas, ruas, parques e praças; demarcar a fronteira entre o espaço público e o privado; ordenar o espaço urbano.

Para Senett, 1 "[...] uma cidade aberta trabalharia com as suas complexidades" [...] $\mathrm{O}$ papel do planejador urbano e do arquiteto seria ao mesmo tempo estimular a complexidade e criar uma ville interativa e sinergética "maior que a soma de suas partes [...]"; a do governante, o de garantir que todos possam ter acesso a essa ville: o direito à cidade.

A Constituição de 1988, além de alçar os Municípios à posição de entes federativos, não só criou um Capítulo dedicado à Política Urbana, como o posicionou no Título da Ordem Econômica, tornando-a instrumento de regulação da atividade econômica, desde que atendidas as funções sociais da Cidade.

Significa dizer que o Planejamento Urbano tem um viés de Direito Regulatório da atividade econômica ligada à mercancia da terra urbana, da propriedade e posse fundiárias, que costuma ser obnubilado por sua feição a priori estritamente urbanística; ou, antes, o contrário [...] E essa regulação deve levar em conta as funções sociais da propriedade urbana e, mais do que isso, da cidade.

A Constituição Federal de 1988 simbolizou a positivação da redemocratização brasi- 
leira e um avanço na defesa dos direitos fundamentais, que representaram a proteção de seu epicentro - a dignidade da pessoa humana - e geraram uma responsabilidade ao Poder Público Municipal para sua efetivação. Dentre eles, destacam-se os direitos sociais, presentes não apenas no Capítulo II, do Título II, da Carta Magna, mas também ao longo de seu texto e em outras normas.

Os direitos sociais são fruto da busca por uma maior intervenção estatal a fim de garantir o real acesso a direitos sociais, econômicos e culturais para todos. Eles ganham destaque após um período de mera igualdade formal advinda da Revolução Francesa, que foi liderada pela burguesia que buscava apenas privilégios para si, valendo-se da transformação social, política e jurídica - do Estado Absolutista para o Estado de Direito - com vistas à garantia das liberdades de contratar, de ter e de o Estado se abster de intervir em suas relações jurídicas, a fim de manter o status quo a seu favor.

Os direitos fundamentais sociais, propositalmente posicionados topograficamente antes da organização do Estado para refletir a relevância das liberdades e da igualdade em face da autoridade, passam a identificar a faceta condicionante do Estado Democrático de Direito e da ordem econômica à garantia dos direitos sociais, culturais e econômicos, que permeiam toda a Carta de Outubro.

Enquanto os direitos fundamentais individuais significaram a transformação social, política e jurídica - do Estado Absolutista para o Estado de Direito - com vistas à garantia das liberdades de contratar, de ter e de o Estado se abster de intervir em suas relações jurídicas, a fim de manter o status quo a seu favor, segundo Ingo Wolfgang Sarlet ${ }^{2}$ "[...] os direitos de segunda dimensão podem ser considerados uma densificação do princípio da justiça social", dotados, segundo o art. $5^{\circ}, \S 1^{\circ}$, da Constituição, cláusula aberta que os contém, de eficácia imediata.

No ordenamento jurídico brasileiro, após diversas constituições promulgadas e outorgadas e períodos de regimes totalitários, foi somente em 1988 que o país conseguiu, ao menos em tese, atingir o patamar de um Estado Social e Democrático de Direito que busca:

\footnotetext{
[...] assegurar o exercício dos direitos sociais e individuais, a liberdade, a segurança, o bem-estar, o desenvolvimento, a igualdade e a justiça como valores supremos de uma sociedade fraterna, pluralista e sem preconceitos, fundada na harmonia social e comprometida, na ordem interna e internacional, com a solução pacífica das controvérsias [...]. ${ }^{3}$
}

De acordo com o art. $5^{\circ}, \S 1^{\circ}$, da Constituição, os direitos e garantias fundamentais possuem aplicação imediata. O referido artigo "estabelece para os órgãos estatais a tarefa de reconhecerem, à luz do caso concreto, a maior eficácia possível a todas as normas definidoras de direitos e garantias fundamentais". ${ }^{4}$

Neste sentido, ter eficácia plena e aplicabilidade imediata, que é atributo de todos os direitos fundamentais, e não apenas dos presentes no art. $5^{\circ}$ da Lei Maior, significa que não dependem de normas infraconstitucionais para produzirem efeitos, nem podem ser por elas limitados. Dada sua fundamentalidade, esses direitos possuem também plena justicibilidade, na medida em que podem ser integralmente exigidos em Juízo. ${ }^{5}$

Significa dizer que, em matéria de direitos sociais, o que muitas vezes pareceram ser 
garantias meramente retóricas ou promessas de direitos sociais promovidos por normas programáticas se tornaram, com a força normativa da Constituição, prestações positivas extraíveis diretamente de sua fundamentalidade, como, v.g., saúde, moradia e direito a creches, num movimento conhecido como judicialização das políticas públicas, a maioria delas representadas por ações movidas em face dos Entes Públicos Municipais.

Note-se que os direitos sociais pressupõem que o Estado aja ativamente a fim de superar as desigualdades sociais e garantir justiça material. Percebe-se, assim, o caráter prestacional dos direitos sociais. Entretanto, importa destacar que nem todos os direitos sociais são direitos a prestações estatais, haja vista que também podem ser caracterizados como direitos de defesa, como o direito dos trabalhadores à greve e à liberdade de associação sindical. ${ }^{6}$

Em tempos de constitucionalização do direito da cidade e do princípio da juridicidade $^{7}$ - segundo o qual cabe à Administração observar, mais do que a lei, a própria Constituição, haurindo diretamente de suas regras e princípios os fundamentos de validade de seus atos -, "aplicar a lei de ofício", ${ }^{8}$ na celebre expressão de Seabra Fagundes, deixou de ser uma atividade supostamente autômata para exigir o desenvolvimento dos poderes-deveres de agir dos Poderes Públicos Municipais no campo de suas autonomias em plena sintonia com os valores e princípios que condicionam a própria validade de seus atos, os constitucionais.

Neste diapasão, os direitos sociais, esses que garantem um mínimo de igualdade material, muitas vezes mediante discriminações positivas, para que os cidadãos possam usufruir de suas liberdades, para parte da doutrina constitucionalista, ${ }^{9}$ estariam incluídos, ao lado dos individuais (art. $60, \S 4^{\circ}$, inc. IV, da CRFB), no núcleo intangível da Constituição - seja (i) em razão da fluidez semântica e da densidade moral dos "direitos e garantias individuais", seja (ii) da circunstância de o próprio constituinte haver tornado o rol de direitos expressos na Constituição uma cláusula aberta (art. $5^{\circ}, \S 2^{\circ}$ ), seja porque pode haver direito individual à igualdade - sendo, neste sentido, insuscetíveis de supressão por emenda constitucional ou de alteração tal capaz de violar uma cláusula implícita de proibição do retrocesso social.

São um antídoto contra a desigualdade social; uma forma de redistribuição pelo sistema constitucional de direitos; um princípio constitucional implícito de justiça redistributiva.

Em tempos de pandemia por Covid-19, todavia, os próprios direitos sociais imanentes ao direito à cidade entraram em rota de colisão com o direito à saúde, como, por exemplo, o direito à educação fundamental, que cedeu, num primeiro momento, de forma integral, à prevenção ao contágio por coronavírus, através da paralisação das aulas escolares no âmbito das redes de ensino das Municipalidades Brasil afora, mesmo sem que se pudesse ofertar naquele momento o acesso a plataformas remotas de ensino e aprendizagem. Houve, portanto, um contraste entre direitos fundamentais sociais, em razão dos males causados pelo coronavírus, que deveriam ser resolvidos no âmbito do Estado Democrático de Direito.

Trata-se, neste artigo, de análise acerca do papel normativo dos Municípios no que 
diz respeito ao combate à pandemia por Covid-19, no contexto de um Direito à Cidade que reúne não só uma visão multidisciplinar acerca do fenômeno urbano, como as competências municipais garantidas pela autonomia federativa dos entes públicos locais, em especial, em matéria de saúde pública, bem como do eventual contraste entre o direito à saúde e outros direitos fundamentais, individuais ou sociais.

Diante do reconhecimento da competência normativa dos Municípios em matéria de saúde, em especial no que diz respeito às ações de tratamento dos infectados pelo coronavírus e as próprias à vigilância sanitária e epidemiológica, cumpre averiguar quando o cotejo entre o direito à saúde e outros direitos fundamentais, como a liberdade de ir e vir e de se reunir, por exemplo, teria obedecido aos sobreprincípios ${ }^{10}$ da razoabilidade e da proporcionalidade e quando os teria vulnerado.

Cuidar-se-á também dos conflitos normativos entre Municípios e União, a fim de se verificar se a jurisprudência de exceção em razão da Covid-19, em torno da interpretação da Lei Federal n. 13.979/2020, serviu ao fortalecimento ou amesquinhamento da autonomia municipal.

Paralelamente, cogitar-se-ão daqueles indivíduos que não puderam aderir às regras de prevenção ao contágio por Covid-19 justamente por não disporem de um mínimo existencial "urbano" que lho permitissem e até que ponto a pandemia acirrou as desigualdades sociais, atingindo mais, os mais vulneráveis.

Como metodologia acerca do poder normativo municipal e seus eventuais conflitos com o federal, recorrer-se-á ao mapeamento jurisprudencial, no âmbito do Supremo Tribunal Federal, em matéria de fixação e requisitos do exercício de competências federativas da Urbe em face da União, no que diz respeito a decisões envolvendo a garantia do exercício do poder municipal.

Para o contraste com outros direitos fundamentais, serão enumerados exemplos de confronto que derivem da Lei Federal n. 13.979/2020, vulgarmente denominada Lei do Coronavírus.

Para a análise do acirramento da desigualdade, utilizar-se-ão os dados primários de pesquisas desenvolvidas por instituições acadêmicas em torno do tema Covid e Desigualdade.

\section{OS DIREITOS SOCIAIS E A CIDADE: "MÍNIMO EXISTENCIAL URBANO"}

Além dos direitos sociais fixados no art. $6^{011}$ e espraiados ao longo da Constituição, a Carta de Outubro foi além especificamente em relação ao Direito à Cidade: fixou o ensino fundamental como direito subjetivo da criança - muito antes de se cogitar de quaisquer discussões acerca da fundamentalidade dos direitos sociais, independentemente de legislação interposta, até porque rigorosamente prescindível - e traçou significativas competências municipais em matéria de direitos sociais, inclusive de moradia adequada, assistência social, mais do que de transporte intramunicipal, de mobilidade urbana, segurança, pública, através da Guarda Municipal, e alimentar, e saúde, com destaque para assistência básica e, no caso 
da pandemia, também as ações de vigilância sanitária, podendo-se dizer que um rol extenso de direitos sociais integra um mínimo existencial urbano, adjetivo que se toma a liberdade de apor à expressão consagrada por se constituir eminentemente de direitos sociais de que deve se desincumbir a Urbe.

Passou-se a exigir da Cidade, para muito além da zeladoria dos espaços públicos, da mobilidade urbana, do lazer, da moradia adequada e do trabalho digno, outros tantos direitos fundamentais sociais, entre os quais, a saúde.

Ocorre que os direitos prestacionais dependem de recursos públicos e, nesse ponto, torna-se evidente a crise do Estado Social brasileiro, cujos recursos são escassos e, muitas vezes, mal geridos.

Nesse cenário de orçamento público insuficiente, haveria um conjunto de direitos básicos do cidadão, ínsitos à dignidade da pessoa humana, próprios à garantia da igualdade, sem os quais não seria possível o exercício das liberdades: trata-se do assim denominado mínimo existencial. ${ }^{12}$

Ricardo Lobo Torres, ${ }^{13}$ discorrendo sobre os vários matizes do conceito, no Estado de Polícia derivado da isenção tributária, mínimo até o qual não se tributavam aqueles que não dispunham de recursos, até se converter em direito(s) fundamental(is) no Estado Democrático de Direito, entende que não existe uma definição apriorística dos direitos que contém, devendo ser traduzido em prestações positivas por parte do Estado a partir das quais se Ihes garanta dignidade.

$\mathrm{Na}$ definição daquele que entendia o "tributo como o preço da liberdade", mínimo existencial corresponde ao "direito às condições mínimas de existência humana digna que não pode ser objeto de intervenção do Estado e que ainda exige prestações estatais positivas." 14

Segundo Ana Paula Barcellos, ${ }^{15}$ os direitos que estariam incluídos neste mínimo existencial envolvem, materialmente, educação fundamental, saúde básica e assistência aos desamparados e, sob o ponto de vista formal, para exigi-los, o acesso à justiça, competências que, do ponto de vista material, pertencem aos Municípios.

A Constituição garante ensino fundamental como direito subjetivo das crianças, determina uma série de outras competências legislativas para os Municípios, responsáveis prioritariamente, em matéria de saúde, pela assistência básica - embora, de acordo com o STF, sejam todos os Entes Federativos brasileiros solidariamente responsáveis pela saúde como um todo ${ }^{16}$-, além de assegurar o direito a uma política de habitação social inclusiva e de regularização fundiária urbana entre as políticas urbanas, da cidade.

Esse mínimo existencial, porque deve ser garantido ao cidadão, do ponto de vista material, essencialmente pelos Municípios, pode ser considerado mesmo urbano, afinal, na cidade, deve-se localizar a moradia adequada, garantir o acesso às creches e escolas, aos postos de saúde e hospitais, aos equipamentos culturais, parques, praças e praias, aos locais de trabalho, aos meios de deslocamento, à mobilidade urbana, aos espaços coletivos e tudo o mais que integra o cotidiano da urbe. 
A partir da constatação de que o poder público não consegue garantir universalmente todos os direitos a todas as pessoas, surgiu, na Alemanha, a noção de reserva do possível, que seria a ideia de que os direitos sociais e suas prestações dependeriam da capacidade financeira e da real disponibilidade de recursos pelo Estado, cujas decisões a respeito da alocação do orçamento público são discricionárias, salvo quando constitucionalmente vinculadas, e envolvem os conceitos de proporcionalidade e razoabilidade da prestação. $A$ reserva do possível representaria, neste sentido, em tese, um limite jurídico e fático à concretização dos direitos fundamentais. ${ }^{17}$

No entanto, esse limite não pode servir de embasamento para se suprimir ou restringir direitos conforme o princípio da vedação ao retrocesso social, que constitui uma proteção aos direitos fundamentais e à dignidade da pessoa humana contra a atuação do legislador e da administração pública, ${ }^{18}$ mas passa a exigir do gestor público o ônus argumentativo da demonstração pública das razões republicanas de suas escolhas alocativas prioritárias e da prestação de contas à população acerca de seus gastos.

O direito constitucional à saúde consiste no dever de o Estado prover assistência à saúde de maneira integral, universal e gratuita com o intuito de garantir uma qualidade mínima de vida, dentro de um sistema único de saúde, à população. Sua efetivação não depende apenas do setor da saúde, mas também da execução de políticas públicas que superem as desigualdades sociais e assegurem o pleno desenvolvimento das atuais e futuras gerações. ${ }^{19}$

A fundamentalidade do direito social à saúde decorre da relevância do bem jurídico tutelado, afinal ele é pressuposto para a manutenção de uma vida digna, saudável e de boa qualidade, que é necessária para o usufruto de outros direitos. ${ }^{20}$

Mas fato é que a própria judicialização do direito à saúde acabou por se tornar uma nova rotina administrativa, só que agora ampliada para outros órgãos constitucionais, desde a Defensoria Pública até o Judiciário. E assim o será enquanto não prestada a contento pelos Poderes Públicos.

Com efeito, pela divisão de competências constitucionais posta na Lei do Sistema Único de Saúde (Lei Federal n. 8.080/1990), aos Municípios compete, prioritariamente, a assistência básica; aos Estados, os procedimentos de média complexidade; e à União, os de alta complexidade.

Firmou-se, todavia, a jurisprudência no sentido de caber a todos os entes federativos, de forma solidária, a responsabilidade pela garantia do direito social à saúde. ${ }^{21}$ Contudo, os recursos públicos são limitados e mal distribuídos, alocados conforme interesses políticos - e não necessidades sociais e econômicas - em um país com notória desigualdade socioeconômica. ${ }^{22}$

Não bastassem, pois, todas as dificuldades enfrentadas pela população para ter garantido seu mínimo existencial urbano em matéria de saúde pública perante o Município, muitas vezes tendo que se socorrer do Judiciário para tanto, eis que se abateu sobre o mundo uma pandemia causada pelo vírus Sars-Cov-2, o coronavírus, assim declarada pela 
OMS em 11 de março de 2020.

\section{CIDADE, DIREITO SOCIAL À SAÚDE E PANDEMIA POR COVID-19}

No Brasil, a situação de Emergência em Saúde Pública de Importância Nacional (ESPIN) em decorrência da Infecção Humana pelo novo Coronavírus (2019-nCoV) veio a ser declarada pelo Ministério da Saúde através da Portaria n. 188/2020 e a situação de calamidade fiscal por Covid-19 veio a ser reconhecida pelo Decreto Legislativo n. 06/2020, do Congresso Nacional; no âmbito do Estado do Rio de Janeiro, reconheceu-se a situação de emergência sanitária através do Decreto Estadual n. 46.973/2020; e, no âmbito do Município do Rio de Janeiro, a situação de emergência sanitária foi decretada pelo Decreto Rio n. 47.236/2020, enquanto o estado de calamidade fiscal o foi pelo Decreto Rio n. 47.355/2020, reconhecido tanto pela Assembleia Estadual, através do Decreto-Legislativo Fluminense n. 05/2020, quanto pela Lei Municipal Carioca n. 6.738/2020, por força de uma interpretação do artigo 65 da Lei de Responsabilidade Fiscal literal e conforme o princípio federativo, respectivamente.

\subsection{ESTADO DE EMERGÊNCIA SANITÁRIA POR COVID-19}

Délton Winter de Carvalho, ${ }^{23}$ especialista em Direito dos Desastres, explica a natureza jurídica da Covid-19:

Segundo a OMS, os coronavírus são zoonóticos_, o que significa que são transmitidos de animais para pessoas. [...]

As doenças zoológicas são constantemente associadas a mudanças ou a distúrbios ecológicos ${ }_{-}^{3}$, numa relação direta entre a degradação dos ecossistemas e o surgimento e a difusão dos patógenos da vida selvagem para humanos. ${ }_{-}^{4}$ [...]

Os desastres consistem, conceitualmente, em cataclismo sistêmico de causas que, combinadas, adquirem consequências catastróficas.

Uma concepção dominante de catástrofe nos remete aos impactos humanos e sociais ocasionados pela natureza $a_{-}^{15}$, tais como terremotos, tornados, incêndios. Esta concepção naturalística de catástrofes tende a vincular os desastres a eventos naturais desencadeadores de danos humanos e à propriedade, dotados estes de grande magnitude. Subjaz a esta noção mais tradicional de desastres, uma distinção cartesiana entre homem/natureza, concebendo desastres como aqueles eventos naturais, não habituais e de intensidade irresistível.

No entanto, a evolução tecnológica e científica da Sociedade Contemporânea ocorrida, principalmente, após a industrialização, desencadeou a ampliação da capacidade de intervenção do homem sobre a natureza, havendo, em quase todos desastres denominados naturais, algum fator antropogênico ${ }_{-}^{17}$, o que frequentemente torna as fronteiras entre estes conceitos turvas. Apesar de tais dificuldades conceituais, para fins didáticos, os desastres são constantemente descritos e classificados segundo suas causas, como "naturais", mistos ou antropogênicos. Os desastres naturais são aqueles decorrentes imediatamente de fenômenos naturais, atribuíveis ao exterior do sistema social, sendo frequentemente classificados em categorias de desastres geofísicos, meteorológicos, hidrológicos, climatológicos e biológicos. Entre os exemplos de desastres biológicos, encontram-se as epidemias e as infestações de insetos. [...]

Note-se, portanto, que as pandemias são frequentemente passíveis de se configurarem em desastres biológicos, geralmente sob a classificação de naturais, em dicotomia aos desastres antropogênicos, com as devidas ressalvas já observadas aqui neste texto sobre o critério da "causalidade natural".

Em suas especificidades, este [o do coronavírus] consiste em um verdadeiro desastre ao sistema de saúde pública mundial. ${ }^{24}$ (g.n.)

Não foi à toa que, na decretação da situação de emergência por Covid-19, através 
do Decreto Municipal $\mathrm{n}^{\circ} \mathbf{4 7 . 2 6 3 / 2 0 2 0}$, o Município do Rio de Janeiro, adequadamente, o classifica como tal, com fundamento na legislação de defesa civil:

Art. $1^{\circ}$ Fica declarada Situação de Emergência no Município do Rio de Janeiro, em conformidade com as prescrições contidas no Formulário de Informações do Desastre - FIDE e demais documentos anexos a este Decreto, em virtude do desastre classificado e codificado como DOENCAS INFECCIOSAS VIRAIS - COBRADE 1.5.1.1.0, pela Instrução Normativa $n^{\circ} 2$, de 20 de dezembro de 2016, do então Ministério da Integração Nacional, que estabelece procedimentos e critérios para a decretação de situação de emergência ou estado de calamidade pública pelos Municípios, Estados e pelo Distrito Federal, e para o reconhecimento federal das situações de anormalidade decretadas pelos entes federativos, e dá outras providências. (g.n.)

A Lei do Sistema Nacional de Proteção e Defesa Civil (Lei Federal n. 12.608/12), que disciplina as situações de emergência e de calamidade púbica, dispõe que:

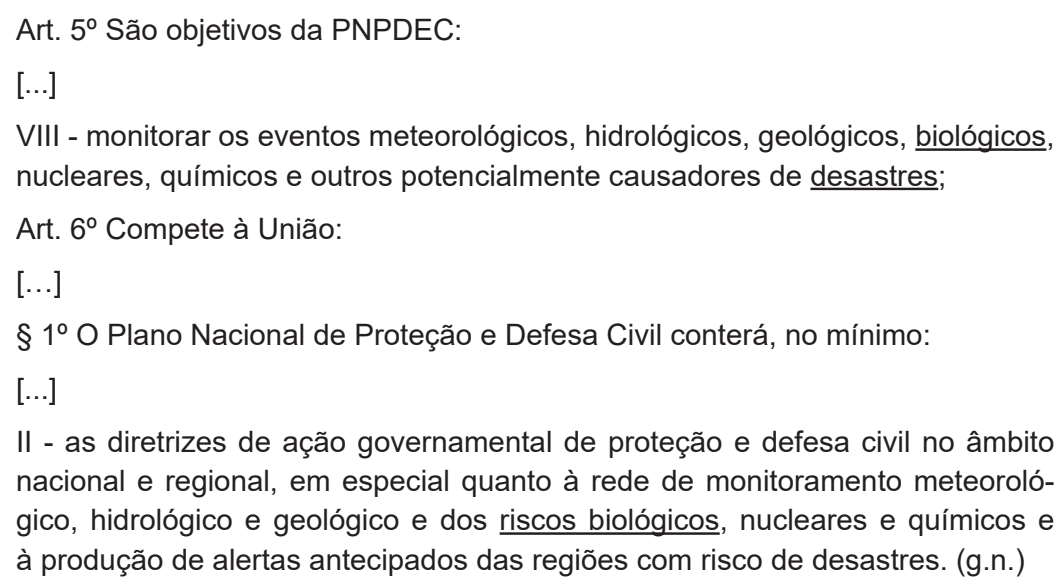
nacional e regional, em especial quanto à rede de monitoramento meteorológico, hidrológico e geológico e dos riscos biológicos, nucleares e químicos e à produção de alertas antecipados das regiões com risco de desastres. (g.n.)

A pandemia por Covid-19 é reconhecida cientificamente, como um desastre biológico, conforme indicado por Délton Winter de Carvalho, ${ }^{25}$ havendo repercussão na população em caráter mundial: daí o termo "pandemia" utilizado. Esse desastre biológico deriva de um desequilíbrio ambiental que decorre per se de uma inobservância a um outro direito fundamental constitucional, desta feita, de terceira geração: ao do meio ambiente ecologicamente equilibrado. Decorre da inobservância ao direito fundamental a cidades sustentáveis.

Neste sentido, não há que se confundir a situação de emergência sanitária com o estado de calamidade fiscal que acometeu a União e, por força da rápida propagação do vírus, pelos demais entes da Federação: enquanto aquele diz respeito à questão sanitária e epidemiológica, este reflete seus impactos financeiros e a flexibilização das exigências de equilíbrio fiscal impostas pelo direito financeiro brasileiro diante da necessidade ${ }^{26}$ irrefreável de prover os gastos destinados ao combate à Covid-19 e, por isso, mitigar as exigências de equilíbrio fiscal que porventura os obstaculizem.

De toda forma, prontamente, a União publicou a Lei Federal n. 13.979/2020, que cuidou de prever medidas drásticas de restrição aos direitos fundamentais em nome da preponderância do direito à saúde, cuja vertente da vigilância sanitária se tornou fundamental para a contenção da expansão do contágio pelo novo vírus SARS-Cov-2 paralelamente ao cuidado aos acometidos da doença da Covid-19.

Com efeito, a Lei Federal n. 13.979/2020 autorizou a adoção das seguintes medidas: 
Art. $2^{\circ}$ Para fins do disposto nesta Lei, considera-se:

I - isolamento: separação de pessoas doentes ou contaminadas, ou de bagagens, meios de transporte, mercadorias ou encomendas postais afetadas, de outros, de maneira a evitar a contaminação ou a propagação do coronavírus; e

II - quarentena: restrição de atividades ou separação de pessoas suspeitas de contaminação das pessoas que não estejam doentes, ou de bagagens, contêineres, animais, meios de transporte ou mercadorias suspeitos de contaminação, de maneira a evitar a possível contaminação ou a propagação do coronavírus.

Art. $3^{\circ}$ Para enfrentamento da emergência de saúde pública de importância internacional decorrente do coronavírus, as autoridades poderão adotar, no âmbito de suas competências, dentre outras, as seguintes medidas: (Redação dada pela Medida Provisória $n^{\circ}$ 926, de 2020)

I - isolamento;

II - quarentena;

$[\ldots]$

$\S 1^{\circ}$ As medidas previstas neste artigo somente poderão ser determinadas com base em evidências científicas e em análises sobre as informações estratégicas em saúde e deverão ser limitadas no tempo e no espaço ao mínimo indispensável à promoção e à preservação da saúde pública.

$[\ldots]$

$\S 7^{\circ}$ As medidas previstas neste artigo poderão ser adotadas:

I - pelo Ministério da Saúde;

II - pelos gestores locais de saúde, desde que autorizados pelo Ministério da Saúde, nas hipóteses dos incisos I, II, V, VI e VIII do caput deste artigo; ou

III - pelos gestores locais de saúde, nas hipóteses dos incisos III, IV e VII do caput deste artigo. (g.n.)

Quarentena e confinamento são medidas de restrição às liberdades de ir e vir, de autonomia da vontade, de livre iniciativa e empresa e de reunião, que, longe dos estados de exceção constitucional - nos quais também são constitucionalmente permitidas restrições às liberdades ambulatoriais e de reunião, por exemplo, mas com sério comprometimento ao Estado Democrático de Direito -, significaram apenas medidas recomendadas pelo Poder Público como forma de contenção do contágio pelo coronavírus antes que o surto pandêmico atingisse uma quantidade tal de cidadãos que o sistema de saúde não pudesse mais suportar o número de possíveis infectados pela doença, mas não deixaram de significar uma ponderação com o direito à saúde no qual este veio a preponderar em relação aos demais.

Houve, portanto, na colisão entre direitos fundamentais, a verificação de o quanto o sacrifício às liberdades de ir e vir, de reunião, de livre iniciativa, de autonomia da vontade, de liberdade econômica significaram ônus proporcionalmente menor em relação ao benefício das vidas poupadas do contágio pelo mortal e implacável coronavírus.

Restava, porém, definir (i) qual ente federativo seria competente para estabelecer quais atividades seriam consideradas essenciais o bastante para permitir que tais medidas pudessem ser flexibilizadas, como o ir e vir dos próprios profissionais encarregados de manter o sistema de saúde funcionando em permanente situação de emergência e (ii) neste caso, como essa regulação deveria obedecer aos sobreprincípios da razoabilidade e da proporcionalidade. 


\subsection{COMPETENCIA CONCORRENTE DOS ENTES ESTADUAIS E, SUPLEMENTAR, DOS MUNICIPAIS}

Na primeira hipótese - de perquirição sobre se caberia somente à União definir quais seriam os serviços essenciais (e essa definição implicava sérias consequências à liberdade econômica, por exemplo) ou aos demais Entes Federativos, no âmbito de seus territórios -, coube ao Supremo Tribunal Federal definir a questão.

A Suprema Corte reconheceu, no julgamento da ADI n. 6341, numa interpretação do artigo $3^{\circ}$ do referido diploma legal conforme a Constituição, a competência de Estados-Membros, Distrito Federal e Municípios para disciplinar os institutos por meio de atos normativos e administrativos, de forma delimitada no tempo e no espaço.

Assim, caiu a exigência de autorização do Ministério da Saúde prevista no $§ 7^{\circ}$, inc. II, do mesmo art. $3^{\circ}$ da "Lei do Coronavírus" e se legitimaram as regulamentações dos institutos do isolamento e, em especial, da quarentena, com sua restrição de atividades e separação das pessoas suspeitas de contaminação (em suas casas) já tipificados em lei de conteúdo, neste ponto, nacional, tendo o Supremo Tribunal Federal reconhecido a competência concorrente legislativa de todos os Entes Federativos brasileiros acerca da matéria, como de resto já inferira dos artigos 196 a 198 do texto constitucional a responsabilidade solidária de todos pelo direito coletivo à saúde. ${ }^{27}$

Com efeito, no julgamento da Arguição de Descumprimento de Preceito Fundamental n. 672/DF, a Corte Suprema, entendendo que a política pública de saúde consistiria de preceitos fundamentais que poderiam estar sendo violados, assim como o princípio federativo e a separação dos poderes, reconheceu a competência concorrente de Estados e Distrito Federal e, suplementar, dos Municípios, para tratar de saúde (art. 23, inc. II e IX) e, portanto, do combate ao coronavírus, com fundamento nos artigos 24 , inc. XII c/c 25 , $\S 1^{\circ}$ c/c 30, inc. II, da Constituição, de modo que assegurou aos governos estaduais, distrital e municipais, no exercício de suas atribuições e no âmbito de seus territórios, competência para a adoção ou manutenção de medidas restritivas durante a pandemia da Covid-19, tais como a imposição de distanciamento social, suspensão de atividades de ensino, restrições de comércio, atividades culturais, circulação de pessoas, entre outras.

Na linha da proteção e prevenção aos riscos à saúde provocados pelo perigo de contágio pelo vírus SARS-CoV-2 à população carioca, com base nos institutos da quarentena e do isolamento já definidos, bem como no exercício da vigilância sanitária da ocupação humana do território municipal, sem falar na nova conotação que assume, em tempos pandêmicos, o exercício das funções sociais da Cidade e de um meio ambiente ecologicamente equilibrado postos na Lei Maior, estabeleceram-se, no plano normativo e administrativo, uma série de medidas restritivas à liberdade deambular, de reunião e de livre iniciativa e de autonomia privada, todas embasadas em estudos exarados por uma Comissão Cientifica formada por especialistas das mais diversas áreas do saber.

Se o ato normativo se legitimou pela decisão da Corte Suprema de Justiça, o ato administrativo passou a contar com um novo requisito de validade: o de estar lastreado em evidências científicas ou dados estatísticos de saúde aptos a justificar e legitimar perante a 
sociedade, o que mais tarde veio a ser enfaticamente reconhecido pelo Supremo Tribunal Federal, sob pena de responsabilidade do agente público.

Com efeito, nos julgamentos das ações diretas de inconstitucionalidade ${ }^{28}$ acerca da Medida Provisória n. 966/2020, a Corte Suprema entendeu que os atos de agentes públicos, em relação à pandemia da Covid-19, devem observar critérios técnicos e científicos de entidades médicas e sanitárias, observando-se, assim, o princípio da precaução. A Corte julgou que o artigo $2^{\circ}$ da Medida Provisória deveria ser interpretado conforme a Constituição, para que se configure como erro grosseiro o ato administrativo que ensejar violação do direito à vida, à saúde ou ao meio ambiente equilibrado em razão da inobservância de normas e critérios científicos e técnicos.

Além disso, a matéria já continha disciplinamento no recente Código de Vigilância Sanitária, Vigilância de Zoonoses e de Inspeção Agropecuária (Lei Municipal n. 197/2018).

Coube, assim, às Cidades, a partir de evidências científicas e de dados estratégicos de saúde relativos a indicadores como índice de letalidade do vírus, posicionamento da curva de crescimento dos contagiados e nível de ocupação de leitos pelos atingidos pelo coronavírus, definir as raras atividades que poderiam ser total ou parcialmente exercidas, ficando todas as demais qualificadas como não essenciais e, quem as exercia, sujeito à quarentena.

O exercício do poder normativo por parte das Municipalidades permitiu que uma verdadeira política pública de combate e prevenção ao contágio pelo coronavírus pudesse ser implantada pelos Chefes dos Executivos e Secretários e Gestores Locais de Saúde e Vigilância Sanitária e Epidemiológica através de atos dotados de normatividade, como decretos, resoluções e portarias, que, muitas vezes, foram publicados no dia mesmo em que deveriam começar gozar de vigência e eficácia, de modo que a Administração fosse, se não tão ágil, o menos "atrasada" o possível em relação à capacidade anônima e veloz do contágio viral pelo SARS-Cov-2.

Observe-se, porém, que as medidas compulsórias preconizadas pela Lei do coronavírus, como quarentena, isolamento, sepultamento com caixão cerrado, requisição administrativa de bens e serviços e compartilhamento compulsório de dados, por exemplo, implicaram restrições a direitos fundamentais tais como a livre iniciativa, a autonomia individual e as liberdades de locomoção e reunião que muitas vezes foram totalmente preteridos em nome do direito à saúde, como até deveriam ser, mas que, em outras, restaram razoável e desproporcionalmente comprometidos.

\subsection{CRITÉRIOS DE CONSTITUCIONALIDADE BALIZADORES DAS MEDIDAS RESTRITIVAS A DIREITOS}

Imperioso delimitar os critérios de constitucionalidade desse poder normativo reconhecido aos Municípios: a uma, respeitar os limites do exercício da competência concorrente à luz do princípio da "hierarquia" (estritamente em relação às normas gerais) e do decidido pelo STF na ADPF 672; a duas, o lastro em evidências científicas ou em dados estatísticos de saúde; a três, a prévia tipificação legal (princípio da 
legalidade, ainda que fosse a Lei Federal n. 13.979/2020); a quatro, a razoabilidade e a proporcionalidade das medidas tomadas pela Cidade; e, a cinco, sua finalidade, de efetivo combate à Covid-19 e não quaisquer outros fins, ainda mais por se tratar de um ano de eleições municipais.

Em que pese, no âmbito da competência concorrente dos Municípios, se verifique a prevalência das normas gerais federais sobre as demais, aspecto considerado expressamente no deslinde de inúmeros julgados, na prática tem se mostrado extremamente sutil e controvertida a definição do que seja "legislação prevalente" ou a sempre debatida "norma geral", razão pela qual não à toa se viu frequente a judicialização de demandas.

Da análise minuciosa dos termos consignados no Voto do Ministro Relator Alexandre de Moraes na ADPF 672, depreende-se a sobreposição, naquele caso concreto, de regras mais severas de outros entes federativos que não a União, aptas a proporcionar maior segurança à saúde pública, ainda que em dissonância ao posicionamento do ente federal. A delicada divergência de posicionamentos entre os entes federativos que, se mal conduzida fosse, poderia estremecer o próprio pacto federativo, teve de ser cuidadosamente contornada pelo Relator.

Naquele julgamento, foi considerado que medidas que neguem a existência ou relevância da pandemia enquanto risco para os direitos constitucionais à vida e saúde vão de encontro aos estudos científicos. Registrou, ainda, a configuração de falta de coerência lógica na conduta e que, diante do dever inerente às autoridades públicas de proteger os direitos à vida e à saúde, quando o Poder Executivo Federal promove políticas decorrentes de decisões de tal cunho, estariam as mesmas eivadas em vícios, sujeitando-as, por conseguinte, à revisão judicial. ${ }^{29}$

Como consequência, a regra legal aplicável seria a mais severa naquele caso, que, fatalmente, não sendo a federal, seria municipal ou estadual, conferindo a ideia superficial de prevalência da regra específica quando, tecnicamente, o que teria ocorrido seria a não aplicação de norma federal, porquanto ilegal, e não em função da competência concorrente ou do princípio da especialidade, mas em razão da menor proteção contra o risco do coronavírus.

Em outro cenário, na STP 676,30 discutiu-se a reabertura de escola militar no município de Belo Horizonte - MG. Apesar da irresignação do município contra a decisão de reabertura da escola militar, o que contrariou as políticas de prevenção municipais, aparentemente mais severas, o STF entendeu pela prevalência da decisão da instituição federal de retornar seu funcionamento em detrimento ao posicionamento municipal de suspendê-lo.

O Relator Ministro Luiz Fux suscitou, em seu voto, dentre os argumentos, que teriam sido tomadas "rigorosas providências técnicas e sanitárias adotadas pelo Sistema Colégio Militar do Brasil e pelo Colégio Militar de Belo Horizonte", e que, diante da "existência de controvérsia efetiva acerca das recomendações técnico-científicas aplicáveis à discussão", não deveria ser concedida a contracautela pleiteada pelo Município. Por tal linha de pensamento, restrições a direitos somente seriam permitidas diante da comprovação de ineficiência das metodologias de prevenção adotadas para a reabertura, o que enseja 


\title{
dúvidas sobre uma possível inversão da lógica utilizada na ADPF $672 .^{31}$
}

$\mathrm{Na}$ RCL 42637, ${ }^{32}$ discutiram-se as competências dos entes federativos à luz do decidido na ADI $6341 \mathrm{MC} .{ }^{33}$ No caso concreto, o TJMG havia determinado que todos os municípios seguissem o posicionamento do respectivo Estado, o que teria acarretado violação à competência legislativa dos municípios e desproporcionalidade na imposição das mesmas medidas a todos os municípios sem observância das características e peculiaridades de cada região.

Nesta oportunidade, restou consignado no voto do Ministro Relator Alexandre de Moraes assistir razão ao Município entendendo que "[...] a dinâmica estabelecida pelo ato impugnado, ao impor aos municípios, de forma absoluta, as regras da Deliberação $n^{\circ} 17 / 2020$ e da Lei Estadual 13.317/1999 caminha, inevitavelmente, na contramão do federalismo cooperativo, em efetivo prejuízo ao princípio da predominância do interesse local [...]", finalizando com a seguinte conclusão:

\begin{abstract}
Nessas circunstâncias, o Tribunal de origem, ao impor as normas estabelecidas no âmbito estadual aos municípios, acabou por esvaziar a competência própria dos municípios do Estado de Minas Gerais para dispor, mediante decreto, sobre o funcionamento dos serviços públicos e atividades essenciais durante o período de enfrentamento da pandemia, ofendendo, por consequência, o decidido por esta CORTE na ADI 6341 (Redator p/ o Acórdão Min. Edson Fachin, Pleno, julgamento em 15/4/2020).
\end{abstract}

Nessa linha, um dos vieses da análise relativa à proporcionalidade e razoabilidade das decisões, no que tange à identificação e divisão de competências, seria distinguir a norma geral do interesse regional, contraposto ao interesse local; a competência municipal em face da estadual, haja vista a assimetria de municipalidades num mesmo território estadual, o princípio da proteção mais rigorosa contra a ameaça de Covid-19 e o daquela que respeitasse ao mesmo tempo a autonomia do ente federativo e a proteção cientificamente melhor embasada. Trata-se de uma jurisprudência de exceção, construída num cenário de avanço galopante da Covid-19 mundo afora e de suas vítimas fatais.

Diante da disparidade da realidade dos entes sobre os quais se legisla, como no caso da tentativa de aplicação da lei estadual sobre todos os municípios indistintamente, verificou-se uma predominância na análise à luz das necessidades locais como medida de razoabilidade, aplicando-se o princípio da subsidiariedade, ou o da "especialidade" (interesse local) em detrimento do princípio da "hierarquia" (das normas gerais federais), tendo este sido constantemente invocado em decisões que têm por fundamento justamente a competência concorrente dos entes federativos para legislar sobre a saúde. ${ }^{34}$

Outro importante filtro da validade dos atos administrativos praticados durante a pandemia é a finalidade do ato administrativo, que não pode ser praticado para fins outros, mas sob o pretexto do combate à Covid-19.

A finalidade do ato administrativo exige que se cumpra o fim a que ele se destina, não podendo ser desviado de rota, sob pena de malferir princípios como os da impessoalidade e da moralidade, mas vai muito além disso. Durante a pandemia, frequentemente, divergências judicializadas sobre a competência legislativa foram solucionadas em função da matéria, promovendo um mix entre os conceitos de finalidade e matéria legislativa. 
Mais especificamente, dispositivos legais versando sobre matérias que desbordariam da competência legislativa de determinado ente foram consideradas constitucionais em razão de terem por finalidade a proteção do direito à vida, à saúde pública e/ou combate à pandemia de COVID-19, atraindo a aplicação da regra da competência legislativa concorrente. Isto é, diante da concomitância de matérias legislativas, analisou-se a finalidade da norma, prevalecendo a análise voltada para o direito à saúde sobre as demais..$^{35} 36$

Muito relevante é o contorno conferido à finalidade à luz da destinação de receitas após a entrada em vigor da Emenda Constitucional n. 106, de 07 de maio de 2020, e da Lei Complementar n. 173/2020, de 27 de maio de 2020, diplomas legais responsáveis pelo estabelecimento do Programa Federativo de Enfrentamento ao Coronavírus SARS-CoV-2 (Covid-19), prevendo mecanismos pautados na flexibilização de restrições previstas na temida Lei de Responsabilidade Fiscal, transferência de recursos da União, ${ }^{37}$ etc.

A Emenda Constitucional n. 106, batizada como "orçamento de guerra", é precisa, já em seu artigo $1^{\circ}$, acerca da excepcionalidade e temporariedade que lhe são características, bem como da imprescindibilidade de que a finalidade do ato esteja voltada para o combate à pandemia como condicionante para as flexibilizações que promove. ${ }^{38}$ Por sua vez, a Lei Complementar n. 173/2020, ao alterar o artigo 65, da Lei de Responsabilidade Fiscal, inseriu como condicionante para fruição de alguns benefícios "que os recursos arrecadados sejam destinados ao combate à calamidade pública".

Nessa linha, na SLS n. 2794, o STJ, em sede de decisão monocrática, entendeu que configura desvio de finalidade a utilização de recursos provenientes da LC 173/2020 para outros fins que não ações de saúde e assistência social voltadas para o combate ao coronavírus. ${ }^{39}$ Ou seja, o auxílio financeiro não pode ter uma predestinação por parte dos entes públicos beneficiados, porque há uma premissa objetiva de que a flexibilização do comprometimento fiscal do Estado só e possível em relação às despesas com a pandemia, não podendo ser desviados seus recursos para quaisquer outros fins.

Por tais razões, a despeito de uma política judicial de selfrestraint, o Judiciário na maior parte das vezes, legitimou os atos restritivos, apoiados em evidências científicas, impostos pelos Poderes Públicos, mas reconheceu eventualmente excessos da Cidade, não só na restrição de direitos fundamentais em nome do bem coletivo saúde, como também no desvio de finalidade de seus atos em relação ao efetivo combate à pandemia.

No quadro geral, pode-se concluir que o Supremo Tribunal garantiu aos Municípios uma autonomia responsável e baseada no princípio da precaução, norteada por adequação a critérios técnicos e científicos, ponderação entre normas gerais e interesse (preponderantemente) local no exercício da competência concorrente em matéria de saúde e observância ao pacto federativo, com preservação ao máximo da autonomia de todos os entes federativos, no combate ao coronavírus, reafirmando, em muitas oportunidades, o protagonismo da Cidade neste momento crucial da história humana. 


\section{CIDADE E DESIGUALDADE SOCIAL}

No seu papel gestor, os Municípios têm restringido diversos direitos em prol do combate ao SARS-Cov-2 e da defesa do direito à saúde. Dentre eles, pode-se aludir a limitação ao direito de ir e vir; ${ }^{40}$ a proibição de aglomerações e reuniões presenciais; ${ }^{41}$ a restrição à livre iniciativa e à autonomia da vontade; ${ }^{42}$ e a proibição da suspensão de serviços essenciais como o fornecimento de água, gás e energia. ${ }^{43}$

A conjuntura de pandemia impactou fortemente o cotidiano de todas as pessoas, principalmente das de classe baixa, negras e da periferia, que já sofrem diversos outros problemas cotidianamente. Tais pessoas, quando conseguem acessar a justiça, recorrem ao Judiciário para terem seus direitos menos violados, pleiteando, v.g., a redução de seus aluguéis ${ }^{44}$ e mensalidades escolares, ${ }^{45} \mathrm{o}$ impedimento do corte de sua energia e o parcelamento de seus débitos. ${ }^{46}$ São elas quem mais sentem as desigualdades sociais e os impactos negativos da pandemia.

É possível se observar que todas as ordens da etiqueta anti-covid ou das regras de ouro ministradas pela Cidade soaram, muitas vezes, elitistas, inverossímeis ou autoritárias para grande parte da população, tais como, "Fique em casa", "Lave as mãos", "Use álcool gel" e "Mantenha distanciamento social".

Trata-se daqueles a quem o direito à prevenção ao contágio restou proscrito não em razão da política pública municipal adotada, mas, diante de omissões estatais históricas e atuais, por integrarem partes da cidade onde o trabalho informal presencial é a única forma de obtenção de renda possível, a metragem quadrada média das habitações e o alto índice de coabitação familiar impedem que se mantenha distanciamento social em relação a membros da família mais vulneráveis e a falta de saneamento básico inviabiliza que o lavar as mãos seja a garantia de não contágio de todo e qualquer vírus.

A Covid-19 também sofreria os influxos do racismo estrutural brasileiro. Resultados de um estudo do Núcleo de Operações e Inteligência em Saúde, grupo da PUC-Rio, ${ }^{47}$ confirmam que pretos e pardos morreram por Covid-19 mais do que brancos no Brasil.

\footnotetext{
O grupo analisou a variação da taxa de letalidade da doença no Brasil de acordo com variáveis demográficas e socioeconômicas da população. Cerca de 30 mil casos de notificações de covid-19 até 18 de maio disponibilizados pelo Ministério da Saúde foram levados em conta.

Considerando esses casos, quase $55 \%$ de pretos e pardos morreram, enquanto, entre pessoas brancas, esse valor ficou em $38 \%$. A porcentagem foi maior entre pessoas negras do que entre brancas em todas as faixas etárias e também comparando todos os níveis de escolaridade.

O estudo também concluiu que, quanto maior a escolaridade, menor a letalidade da covid-19 nos pacientes. Pessoas sem escolaridade tiveram taxas três vezes superiores $(71,3 \%)$ às pessoas com nível superior $(22,5 \%)$.

Cruzando escolaridade com raça, então, a coisa piora: pretos e pardos sem escolaridade tiveram $80,35 \%$ de taxas de morte, contra $19,65 \%$ dos brancos com nível superior.
}

"A desigualdade social tem impacto direto nos óbitos entre os mais pobres e com menor escolaridade", ${ }^{48}$ diz, por e-mail, uma das pesquisadoras responsáveis pelo estudo, Paula Maçaira, pesquisadora do Departamento de Engenharia Industrial do CTC/PUC-Rio e integrante do NOIS - Núcleo de Operações e Inteligência em Saúde. "Quanto mais desfavo- 
rável a situação do paciente, mais chances ele tem de falecer."49

A percepção do medo e, por isso, os cuidados, porém, são maiores entre os moradores de assentamentos precários em relação ao resto da cidade. Pesquisa realizada pela Universidade do Estado do Rio de Janeiro ${ }^{50}$ mostrou que, nas favelas, a percepção de medo da Covid-19 é maior do que no asfalto, o que leva seus moradores a adotarem as medidas de prevenção de maneira muito mais cuidadosa.

\begin{abstract}
O Laboratório de Análise da Violência do Instituto de Ciências Sociais da Universidade do Estado do Rio de Janeiro (LAV-Uerj) realizou a pesquisa "Coronavírus: medo, percepções e crenças", entre os dias 4 e 15 de maio, pela internet, com 1.203 moradores da cidade do Rio de Janeiro. O estudo mostrou que os reflexos do isolamento social e o medo do vírus são uma realidade na vida de todos os entrevistados, mas a condição social e as crenças políticas ditam o quanto a pessoa vai ser afetada por esse medo. [...]

Números demonstram diferenças de ordem social

A pesquisa mostrou que o medo da doença é maior para os moradores de favela, que também se expõem mais. Entre eles, $77,2 \%$ evitaram pegar algum transporte coletivo, contra $92,9 \%$ dos que residem fora de comunidades; $72,6 \%$ deixaram de trabalhar fora de casa, contra $81,4 \%$ dos demais moradores da cidade. E 84,4\% evitaram encontrar familiares e amigos, uma realidade para $97,2 \%$ dos cariocas do asfalto. Na favela, $71,8 \%$ dos habitantes temem o SARS-CoV-2 contra $55,6 \%$ fora dela, enquanto $56 \%$ têm medo de morrer por Covid-19, em comparação a $33,7 \%$ do restante da população.
\end{abstract}

Em matéria de Direito dos Desastres, para os quais deve sempre haver a devida gestão de riscos, certo é que os indivíduos em situação de maior vulnerabilidade serão sempre, em caso de sinistro, os mais atingidos: no caso das chuvas torrenciais, os que morem em encostas; no caso do coronavírus, os que contem com histórico de saúde comprometido, que concorra para a existência de comorbidades, os que morem em lugares mais adensados, com pouca aeração e saneamento precário, que facilitem exponencialmente a proliferação do vírus, e os que tenham famílias numerosas em coabitação num mesmo imóvel, contribuindo igualmente para a contaminação de todos.

Não é à toa que lemos, em alguma das inúmeras pesquisas produzidas durante a pandemia, que, no Brasil, o vírus que mais mata não é o corona, mas a desigualdade.

Resta, finalmente, cogitar qual cidade, sob a perspectiva do SUS, se terá ou se deverá buscar ter, pós Covid-19. Quais lições a Cidade e seu sistema de saúde aprenderam com a pandemia? Como a Covid-19, assim como outros desastres, cujos riscos cabe à Cidade gerir, revelam a vulnerabilidade superlativa daqueles que moram em condições precárias? Se o problema não é tanto ou somente o desastre, mas a desigualdade per se, o que fazer?

Amartya Sem ${ }^{51}$ responde a pergunta com a garantia das liberdades, firme na convicção de que elas assegurarão igualdade e, até mesmo, desenvolvimento, porque, através delas e da emancipação democrática, o indivíduo é capaz de fazer valer seus direitos, de não ter fome a se desenvolver economicamente.

O Sistema Único de Saúde, apesar de todas as mazelas, sairá maior da Covid-19, mas é preciso que a política pública de moradia popular passe a merecer maior investimento por parte da Cidade. Para João Sette, uma vinculação orçamentária constitucional, tal qual existe na Saúde e na Educação, ajudaria bastante. 


\section{NOTAS}

1. SENNETT, R. Construir e Habitar. Rio de Janeiro/São Paulo: Record, 2018, p. 19.

2. SARLET, Ingo Wolfgang. A eficácia dos direitos fundamentais. Porto Alegre: Livraria do Advogado: 2001, p. 50.

3. BRASIL. Constituição da República. Preâmbulo da Constituição da República Federativa do Brasil de 1988.

4. SARLET, Ingo Wolfgang. Os Direitos Fundamentais Sociais na Constituição de 1988, Revista Diálogo Jurídico, ano I, vol. I, nº. 1, Salvador, 2001, p. 29.

5. ibid., p. 31.

6. ibid., p. 18-19.

7. SESIN, Domingo J. Administración Pública. Actividad Reglada, Discrecional e Técnica. Buenos Aires: Depalma, 1994. ENTERRIA, García de. e RAMON FERNANDEZ, Tomás. Curso de Derecho Administrativo. Madrid: Civitas, 1999, v. I, p. 429. OTERO, Paulo. Legalidade e Administração Pública: o sentido da vinculação administrativa à juridicidade. Coimbra: Almedina, 2003.

8. FAGUNDES, Miguel Seabra. O Controle dos Atos Administrativos pelo Poder Judiciário. 5. ed. Rio de Janeiro: Forense, 1979, p. 4-5.

9. SARLET, Ingo W. A problemática dos direitos fundamentais sociais como limites materiais ao poder de reforma da constituição. In: SARLET, Ingo W. Direitos Fundamentais Sociais: Estudos de Direito Constitucional, Internacional e Comparado. Rio de Janeiro: Renovar, 2003.

10. Segundo Humberto Ávila, razoabilidade e proporcionalidade são princípios que auxiliam o interprete na interpretação de outros princípios, de modo que deveriam receber o adjetivo de sobreprincípios. (AVILA, Humberto. Teoria dos Princípios: da definição à aplicação dos princípios jurídicos. 17. ed. São Paulo: Malheiros, 2019).

\section{CRFB}

Art. $6^{\circ}$ São direitos sociais a educação, a saúde, a alimentação, o trabalho, a moradia, o transporte, o lazer, a segurança, a previdência social, a proteção à maternidade e à infância, a assistência aos desamparados, na forma desta Constituição. (g.n.)

12. Para outras conceituações de mínimo existencial, confira-se: CARDOSO, Itala Lopes; CUNHA, Jarbas Ricardo Almeida. O mínimo existencial do direito à saúde no SUS: o caso do Programa Saúde da Família. Cadernos Ibero-Americanos de Direito Sanitário, Brasília, 5(4):9-26, out./dez, 2016, p. 5-7.

13. TORRES, Ricardo Lobo. Tratado de Direito Constitucional Financeiro e Tributário. v. III Os Direitos Humanos e a Tributação - imunidades e isonomia. Rio de Janeiro: Renovar, 1999.

14. op. cit., p. 141.

15. BARCELlos, Ana Paula de. A Eficácia Jurídica dos Princípios Constitucionais - O princípio da dignidade da pessoa humana. 2 ed. Rio de Janeiro: Renovar, 2008.

16. RE 855178 - RE -Repercussão Geral - Tema 793 - Tese:

Os entes da federação, em decorrência da competência comum, são solidariamente responsáveis nas demandas prestacionais na área da saúde, e diante dos critérios constitucionais de descentralização e hierarquização, compete à autoridade judicial direcionar o cumprimento conforme as regras de repartição de competências e determinar o ressarcimento a quem suportou o ônus financeiro.

17. SARLET, Ingo Wolfgang. Direitos fundamentais a prestações sociais e crise: algumas aproximações. 
Espaço Jurídico Journal of Law, Joaçaba, v. 16, n. 2, p. 459-488, jul./dez. 2015, p. 470-471.

18. ibid., p. 477.

19. SARLET, Ingo Wolfgang; FIGUEIREDO, Mariana Filchtiner. Algumas considerações sobre o direito fundamental à proteção e promoção da saúde aos 20 anos da Constituição Federal de 1988. Revista de Direito do Consumidor, n. 67, 2008, p. 4.

20. ibid., p. 5.

21. EMENTA: RECURSO EXTRAORDINÁRIO. CONSTITUCIONAL E ADMINISTRATIVO. DIREITO À SAÚDE. TRATAMENTO MÉDICO. RESPONSABILIDADE SOLIDÁRIA DOS ENTES FEDERADOS. REPERCUSSÃO GERAL RECONHECIDA. REAFIRMAÇÃO DE JURISPRUDÊNCIA. O tratamento médico adequado aos necessitados se insere no rol dos deveres do Estado, porquanto responsabilidade solidária dos entes federados. O polo passivo pode ser composto por qualquer um deles, isoladamente, ou conjuntamente. (RE 855178 RG, Relator(a): LUIZ FUX, Tribunal Pleno, julgado em 05/03/2015, PROCESSO ELETRÔNICO REPERCUSSÃO GERAL - MÉRITO DJe-050 DIVULG 13-03-2015 PUBLIC 16-03-2015) A repercussão geral veio a ser aprovada e votada, passando a ser o Tema 793.

Tese:

Os entes da federação, em decorrência da competência comum, são solidariamente responsáveis nas demandas prestacionais na área da saúde, e diante dos critérios constitucionais de descentralização e hierarquização, compete à autoridade judicial direcionar o cumprimento conforme as regras de repartição de competências e determinar o ressarcimento a quem suportou o ônus financeiro.

22. PEREIRA, Jane Reis Gonçalves. Direitos sociais, estado de direito e desigualdade: reflexões sobre as críticas à judicialização dos direitos prestacionais. Quaestio Juris, v. 8, n. 3, Rio de Janeiro, 2015, p. 2082-2083.

23. CARVALHO, Délton Vinter. A natureza jurídica da pandemia da Covid-19 como um desastre biológico. Conjur, São Paulo, 21 abr. 2020. Disponível em: https://www.conjur.com.br/2020-abr-21/direito-pos-graduacao-natureza-juridica-pandemia-covid-19

-19-desastre-biologico. Acesso em: 20 jun. 2020.

24. Em Live, realizada em 22/06/20, pelo Instituto de Direito Público, para tratar da Desigualdade e Cidade em tempos de Pandemia, a especialista Fernanda Damacena classifica a Covid-19 como um desastre sanitário. Confira em: INSTITUTO BRASILEIRO DE DIREITO PÚBLICO. Cidades e Desigualdades: reflexos do Covid-19 na pandemia. Disponível em: https://www.idp.edu.br/eventos/cidades-e-desigualdades-reflexos-da-pandemia-do-covid-19-grupo- de-estudos-o-direito-em-tempos-de-covid-19/. Acesso em: 15 ago. 2020.

25. CARVALHO, Délton Winter. op. Cit.

26. Através da Medida Cautelar na Ação Direta de Inconstitucionalidade (ADI) 6357, deferida em 29 de março de 2020, o Ministro Alexandre de Moraes, afastou as exigências da Lei de Responsabilidade Fiscal (Lei Complementar Federal n. 101/2000) e da Lei de Diretrizes Orçamentárias (Lei Federal n. 13.898/2019), relativas à demonstração de adequação e compensação orçamentária para a criação e expansão de programas públicos destinados ao enfrentamento da Covid-19 e, no primeiro caso, de ofício, as estendeu a Estados e Municípios, em decisão recentemente referendada pelo Plenário do Supremo Tribunal Federal.

27. RE 855.178-RG, Rel. Min. Luiz Fux (Tema 793)

28. As ações foram ajuizadas pela Rede Sustentabilidade (ADI 6421), pelo Cidadania (ADI 6422), pelo Partido Socialismo e Liberdade (ADI 6424), pelo Partido Comunista do Brasil (ADI 6425), pela Associação 
Brasileira de Imprensa (ADI 6427), pelo Partido Democrático Trabalhista (ADI 6428) e pelo Partido Verde (6431).

29. STF. ADPF 672. Relator Ministro Alexandre de Moraes - Fragmento do Voto do Relator: "Em respeito à Separação de Poderes, ao Presidente da República, como força motriz na condução do Estado nos regimes presidencialistas, compete à chefia da administração pública federal o planejamento e a execução de políticas públicas de âmbito nacional, visando à atenuação dos efeitos sociais e econômicos da pandemia. [...] Ressalte-se, entretanto, que o caráter discricionário das medidas realizadas pelo Presidente da República, bem como de suas eventuais omissões, é passível de controle jurisdicional, pois está vinculado ao império constitucional, exigindo a obediência das autoridades ao Direito, e, em especial, ao respeito e efetividade aos direitos fundamentais. [...] Não compete ao Poder Judiciário substituir o juízo de conveniência e oportunidade realizado pelo Presidente da República no exercício de suas competências constitucionais, porém é seu dever constitucional exercer o juízo de verificação da exatidão do exercício dessa discricionariedade executiva perante a constitucionalidade das medidas tomadas, verificando a realidade dos fatos e também a coerência lógica da decisão com as situações concretas. Se ausente a coerência, as medidas estarão viciadas por infringência ao ordenamento jurídico constitucional e, mais especificamente, ao princípio da proibição da arbitrariedade dos poderes públicos que impede o extravasamento dos limites razoáveis da discricionariedade, evitando que se converta em causa de decisões desprovidas de justificação fática e, consequentemente, arbitrárias". (g.n.) Data de Julgamento: 13/10/2020, Data de Publicação: 29/10/2020.

30. Supremo Tribunal Federal. SUSPENSÃO DE TUTELA PROVISÓRIA 676 MINAS GERAIS. Fragmento da decisão: "Nada obstante, à luz da argumentação formulada pelo Município requerente e dos elementos constantes nos autos não se depreende claramente, acima de dúvida razoável, a existência de potencial lesão de natureza grave ao interesse público a ensejar a concessão da medida pleiteada. Com efeito, nada obstante a decisão administrativa municipal esteja supostamente amparada em um planejamento (Decreto $n^{\circ}$ 17.361, de 22 de maio de 2020), a União, na qualidade de agravante nos autos do processo $n^{\circ} 1031780-$ 72.2020.4.01.0000, aponta "rigorosas providências técnicas e sanitárias adotadas pelo Sistema Colégio Militar do Brasil e pelo Colégio Militar de Belo Horizonte", tendo sido acostados aos autos documentos como: i) o protocolo sanitário elaborado pelo Exército Brasileiro, o qual compreende as medidas de adaptação das atividades pedagógicas; ii) o comunicado emitido pelo Comando e Direção do Colégio Militar de Belo Horizonte com a programação e regras acerca do retorno às aulas (doc. 2, p. 69); e iii) o documento que trata do cumprimento de informações da Requisição (Inquérito Civil no 1.22.000.000625/2020-19) assinado pelo comandante e diretor de ensino do Centro de Preparação de Oficiais da Reserva (CPOR/ $C M-B H)$, atestando a possibilidade de retorno às aulas com segurança, considerando medidas e protocolos adotados (doc. 2, p. 71)". (g.n.) Relator: Ministro Luiz Fux, Data de Julgamento: 21/10/2020, Data de Publicação: 23/10/2020.

31. STF. ADPF 672. "Dessa maneira, não compete ao Poder Executivo federal afastar, unilateralmente, as decisões dos governos estaduais, distrital e municipais que, no exercício de suas competências constitucionais, adotaram ou venham a adotar, no âmbito de seus respectivos territórios, importantes medidas restritivas como a imposição de distanciamento ou isolamento social, quarentena, suspensão de atividades de ensino, restrições de comércio, atividades culturais e à circulação de pessoas, entre outros mecanismos reconhecidamente eficazes para a redução do número de infectados e de óbitos, como demonstram a recomendação da OMS (Organização Mundial de Saúde) e vários estudos técnico-científicos, como, por exemplo, os estudos realizados pelo Imperial College of London, a partir de modelos matemáticos (The Global Impact of COVID-19 and Strategies for Mitigation and Suppression, vários autores; Impact of nonpharmaceutical interventions (NPIs) to reduce COVID-19 mortality and healthcare demand, vários autores)". (g.n.) Relator: Ministro Alexandre de Moraes, Data de Julgamento: 13/10/2020, Data de Publicação: 29/10/2020.

32. STF. RCL 42.637. Relator: Ministro Alexandre de Moraes. Data de Julgamento: 09/09/2020, Data de Publicação: 24/09/2020.

33. "REFERENDO EM MEDIDA CAUTELAR EM AÇÃO DIRETA DA INCONSTITUCIONALIDADE. DIREITO CONSTITUCIONAL. DIREITO À SAÚDE. EMERGÊNCIA SANITÁRIA INTERNACIONAL. LEI 13.979 
DE 2020. COMPETÊNCIA DOS ENTES FEDERADOS PARA LEGISLAR E ADOTAR MEDIDAS SANITÁRIAS DE COMBATE À EPIDEMIA INTERNACIONAL. HIERARQUIA DO SISTEMA ÚNICO DE SAÚDE. COMPETÊNCIA COMUM. [...] 4. A diretriz constitucional da hierarquização, constante do caput do art. 198 não significou hierarquização entre os entes federados, mas comando único, dentro de cada um deles. 5. É preciso ler as normas que integram a Lei 13.979, de 2020, como decorrendo da competência própria da União para legislar sobre vigilância epidemiológica, nos termos da Lei Geral do SUS, Lei 8.080, de 1990. 0 exercício da competência da União em nenhum momento diminuiu a competência própria dos demais entes da federação na realização de serviços da saúde, nem poderia, afinal, a diretriz constitucional é a de municipalizar esses serviços. 6 . 0 direito à saúde é garantido por meio da obrigação dos Estados Partes de adotar medidas necessárias para prevenir e tratar as doenças epidêmicas e os entes públicos devem aderir às diretrizes da Organização Mundial da Saúde, não apenas por serem elas obrigatórias nos termos do Artigo 22 da Constituição da Organização Mundial da Saúde (Decreto 26.042, de 17 de dezembro de 1948), mas sobretudo porque contam com a expertise necessária para dar plena eficácia ao direito à saúde. 7. Como a finalidade da atuação dos entes federativos é comum, a solução de conflitos sobre o exercício da competência deve pautar-se pela melhor realização do direito à saúde, amparada em evidências científicas e nas recomendações da Organização Mundial da Saúde. [...]' (ADI 6341 MC-Ref, Relator(a): MARCO AURÉLIO, Relator(a) p/ Acórdão: EDSON FACHIN, Tribunal Pleno, julgado em 15/04/2020, PROCESSO ELETRÔNICO DJe-271 DIVULG 12-11-2020 PUBLIC 13-11-2020) (g.n.)

34. TJRJ. $5^{\text {a }}$ Câmara Cível. MS 0023149-25.2020.8.19.0000. "[...] a competência para adoção das medidas de combate e prevenção à COVID-19, por se tratar de questão afeita à saúde, é concorrente1, como indicado pelo Pleno do Supremo Tribunal Federal, por unanimidade, quando referendou a medida cautelar deferida pelo Relator Min. Marco Aurélio na Ação Direta de Inconstitucionalidade $n^{\circ} 6341$. A ADI citada tem como objeto a Medida Provisória $n^{\circ}$ 926/2020, editada para alterar dispositivos da lei $n^{\circ}$ 13.979/2020, e o STF esclareceu que todos os entes, no respectivo âmbito territorial, podem determinar medidas restritivas durante a pandemia do novo coronavírus. Assim, as providências normativas e administrativas podem ser determinadas pelos Estados, pelo Distrito Federal e pelos Municípios, observado o princípio da hierarquia das normas, segundo o qual a legislação federal tem primazia sobre a estadual e municipal e, a estadual sobre a municipal". (g.n.) Relatora: Desembargadora Cláudia Telles de Menezes, Data de Julgamento: 02/09/2020, Data de Publicação: 04/09/2020.

35. TJRJ AGRAVO DE INSTRUMENTO № 0036587-21.2020.8.19.0000. Nesse caso foi mantida a proibição de realização de obras em condomínio durante a Pandemia. Não obstante a competência legislativa sobre matéria de direito civil ser privativa da União, nos termos do inciso I, do artigo 22, da CRFB/88, a restrição imposta às relações de natureza civil se deu em função do objetivo de combate à pandemia de COVID-19, atraindo a competência concorrente de todos os entes federativos para legislar sobre saúde. Relator: Desembargador Alexandre Antônio Franco Freitas Câmara, Data de Julgamento: 20/07/20, Data de Publicação: 22/07/2020.

36. TJRJ. 0023149-25.2020.8.19.0000. Fragmento do Voto da Desembargadora Relatora Cláudia de Menezes: "[...] Alegam os impetrantes, primeiramente, que a competência para legislar sobre trânsito e transporte é privativa da União e que a BR040 é rodovia de competência federal, não tendo o Prefeito qualquer ingerência sobre seus acessos e saídas. Ocorre que, além de o ato ora impugnado não afetar a BR 040, a competência para adoção das medidas de combate e prevenção à COVID-19, por se tratar de questão afeita à saúde, é concorrente[...]'. (g.n.) Data de Julgamento: 02/09/2020, Data de Publicação: 04/09/2020.

37. LC 173/2020. Art. $1^{\circ}, \S 1^{\circ}$, inc. III: "entrega de recursos da União, na forma de auxílio financeiro, aos Estados, ao Distrito Federal e aos Municípios, no exercício de 2020, e em ações de enfrentamento ao Coronavírus SARS-CoV-2 (Covid-19)".

38. Emenda Constitucional n. 106, de 07 de maio de 2020: "Art. $1^{\circ}$ Durante a vigência de estado de calamidade pública nacional reconhecido pelo Congresso Nacional em razão de emergência de saúde pública de importância internacional decorrente de pandemia, a União adotará regime extraordinário fiscal, 
financeiro e de contratações para atender às necessidades dele decorrentes, somente naquilo em que a urgência for incompatível com o regime regular, nos termos definidos nesta Emenda Constitucional". (g.n.)

39. Superior Tribunal de Justiça. Suspensão de Liminar e de Sentença nº 2794 - MT (2020/0238239-1. Relator Ministro Humberto Martins. Decisão Monocrática. "Como visto, asseverou-se que o propósito do auxílio financeiro estabelecido na Lei Complementar n. 173/2020 é o de promover ações de enfrentamento à covid-19 e o de mitigar seus efeitos financeiros, de modo que a sua a finalidade é vinculada. Assim, a aprovação da Lei Municipal n. 11.022/2020, permitindo a utilização de recursos provenientes da LC n. 173/2020 para outros fins, configura desvio de finalidade da verba, a qual foi destinada exclusivamente para ações de saúde e assistência social". (g.n.) Data de Julgamento: 21/10/2020.

40. "PRETENSÃO DE ESCAPAR DAS DIRETRIZES ESTATAIS QUE LIMITAM O TRÂNSITO DOS CIDADÃOS PELOS ESPAÇOS PÚBLICOS EM FUNÇÃO DA PANDEMIA DE COVID-19. 1 Direito constitucional à livre locomoção em território nacional (art. $5^{\circ}$, inc. XV da CRFB) que não ostenta caráter absoluto. [...] as alegadas restrições de circulação não se mostram abusivas ou ilegais, mas, muito pelo contrário, constituem medidas essenciais para garantia mínima contra disseminação e contaminação dos cidadãos cariocas e fluminenses por um vírus que causa moléstia cujos efeitos podem ser letais quando da sua rápida propagação. Permitir que o paciente ou qualquer outro sujeito tenha o privilégio de não observar restrições preventivas a todos impostas significa criar tratamento diferenciado sem motivação idônea para tanto e, em última análise, fomentar a contaminação massiva de sujeitos mais vulneráveis cuja suscetibilidade a desfechos graves é maior." (TJ-RJ - HC: 0023125-94.2020.8.19.0000, Relatora Desembargadora Maria Angélica Guimarães Guerra Guedes, OE - Secretaria do Tribunal Pleno e Órgão Especial, Data de Julgamento: 26/10/2020, Data de Publicação: 03/11/2020)

41. "IMPOSSIBILIDADE DE REALIZAÇÃO DE ASSEMBLEIA PRESENCIAL DURANTE A PANDEMIA DO COVID 19 EM RAZÃO DO ISOLAMENTO SOCIAL COM A PROIBIÇÃO DE AGLOMERAÇÃO OU REUNIÃO DE PESSOAS FISICAMENTE, DEVENDO O JUIZZO DE ORIGEM, TODAVIA, REALIZÁ-LA NA MODALIDADE VIRTUAL, NOS TERMOS DO ART. 2', PARÁGRAFO ÚNICO, DA REFERIDA RECOMENDAÇÃO N 63 DO CNJ." (TJ-RJ - Al: 0052425-04.2020.8.19.0000, Relator Desembargador Luiz Roldão de Freitas Gomes Filho, Segunda Câmara Cível, Data de Julgamento: 05/10/2020, Data de Publicação: 07/10/2020)

42. "DOCUMENTOS ACOSTADOS AOS AUTOS QUE DEMONSTRAM A VEROSSIMILHANÇA DAS ALEGAÇÕES AUTORAIS, BEM COMO O RISCO DE DANO IRREPARÁVEL CONSUBSTANCIADO NO CANCELAMENTO DO PLANO DE SAÚDE EM MEIO À PANDEMIA DE COVID-19. (...) PREPONDERÂNCIA DOS DIREITOS À SAÚDE E À DIGNIDADE DA PARTE AUTORA SOBRE A AUTONOMIA DE VONTADE DA RÉ." (TJ-RJ - Al: 0045932-11.2020.8.19.0000, Relatora Desembargadora Sandra Santarém Cardinali, Vigésima Sexta Câmara Cível, Data de Julgamento: 17/09/2020, Data de Publicação: 18/09/2020)

43. "A LEI ESTADUAL 8.769/20, QUE DISPÕE SOBRE AS MEDIDAS DE PROTEÇÃO À POPULAÇÃO DO RIO DE JANEIRO DURANTE O PLANO DE CONTINGÊNCIA DO COVID-19 DISPÕEM: "ART. 2०. FICA VEDADA A INTERRUPÇÃO DE SERVIÇOS ESSENCIAIS POR FALTA DE PAGAMENTO, PELAS CONCESSIONÁRIAS DE SERVIÇOS PÚBLICOS.". ATÉ MESMO PARA DÉBITOS ANTIGOS, HÁ VEDAÇÃO LEGAL DE INTERRUPÇÃO DO SERVIÇO DE ENERGIA: $2^{\circ}$ - APÓS O FIM DAS RESTRIÇÕES DECORRENTES DO PLANO DE CONTINGÊNCIA, AS CONCESSIONÁRIAS DE SERVIÇO PÚBLICO, ANTES DE PROCEDER A INTERRUPÇÃO DO SERVIÇO EM RAZÃO DA INADIMPLÊNCIA ANTERIOR A MARÇO DE 2020, DEVERÃO POSSIBILITAR O PARCELAMENTO DO DÉBITO PELO CONSUMIDOR." (TJ-RJ - Al: 0037891-55.2020.8.19.0000, Relatora Desembargadora Inês da Trindade Chaves de Melo, Sexta Câmara Cível, Data de Julgamento: 23/09/2020, Data de Publicação: 02/10/2020)

44. "DESPEJO - LIMINAR DEFERIDA PARA REDUÇÃO DO VALOR DO ALUGUEL E OBSTAR DESPEJO. COVID 19. CARÁTER DE EXCEPCIONALIDADE. Agravo de instrumento em face de decisão que deferiu antecipação de tutela para impedir o despejo da agravada do imóvel locado, bem como autorizar que a mesma efetue o pagamento do valor correspondente a 50\% do aluguel, a contar do mês de abril/2020. 
[...] Necessidade de convalidação da medida de redução do valor locativo. Impactos na vida financeira da agravada, que inclusive desocupou o imóvel." (TJ-RJ - Al: 0051381-47.2020.8.19.0000, Relatora Desembargadora Natacha Nascimento Gomes Tostes Gonçalves de Oliveira, Vigésima Sexta Câmara Cível, Data de Julgamento: 17/09/2020, Data de Publicação: 18/09/2020).

45. "Relação de consumo. Redução de mensalidade em curso de ensino superior em razão da pandemia de covid-19. UNIGRANRIO. Decisão que concede tutela provisória de urgência deferindo desconto de $40 \%$. Insurgência da parte ré. Possibilidade de revisão de cláusulas contratuais com base na onerosidade excessiva (art. $6^{\circ}, V$ do $C D C$ ). Pandemia de covid-19 que afetou significativamente o modo de prestação do serviço de presencial para virtual. Necessidade de reequilíbrio contratual. Dever de solidariedade (art. 3, I da Constituição Federal)." (TJ-RJ - Al: 0046402-42.2020.8.19.0000, Relator Desembargador Peterson Barroso Simão, Terceira Câmara Cível, Data de Julgamento: 19/10/2020, Data de Publicação: 28/10/2020).

46. "Com efeito, a Lei Estadual $n^{\circ}$ 8.769/2020, ao dispor sobre medidas de proteção à população fluminense durante o plano de contingência do COVID-19, proibiu a suspensão dos serviços essenciais por falta de pagamento pelas concessionárias de serviço público. A restrição ao corte do serviço essencial imposta pela legislação estadual não distingue débitos atuais ou pretéritos do consumidor, conforme se extrai da leitura do $\$ 2^{\circ}$, art. $2^{\circ}$ da Lei Estadual $n^{\circ}$ 8.769/2020. [...] quanto à alegada cobrança excessiva do serviço essencial, a jurisprudência deste E. Tribunal de Justiça orienta-se no sentido da possibilidade de a parte autora realizar o pagamento do débito por consignação nos autos, conforme a média registrada nos últimos seis, conforme entendimento sedimentado na Súmula $n^{\circ} 195$ deste TJRJ [...]' (TJ-RJ - Al: 0018961-86.2020.8.19.0000, Relatora Desembargadora Sandra Santarém Cardinali, Vigésima Sexta Câmara Cível, Data de Julgamento: 21/05/2020, Data de Publicação: 22/05/2020).

47. GRAGNANI, Juliana. Por que o coronavírus mata mais as pessoas negras e pobres no Brasil e no mundo? BBC News Brasil, Londres, 12 jul. 2020. Disponível em: https://www.bbc.com/portuguese/ brasil-53338421. Acesso em: 18 nov. 2020.

48. ibid.

49. ibid.

50. UERJ. Pesquisa da Uerj revela influência das desigualdades sociais e crenças políticas na percepção sobre a Covid-19, Rio de Janeiro, UERJ, 2020. Disponível em: https://www.uerj.br/noticia/pesquisa-da-uerj-revela-influencia-das-desigualdades-sociais-e-crencas-politicas-na-percepcao-sobre-a-covid-19/. Acesso em: 18 nov. 2020.

51. SEN, Amartya. Desenvolvimento como liberdade. São Paulo: Companhia das Letras, 2000.

\section{REFERÊNCIAS}

ÁVILA, Humberto. Teoria dos Princípios: da definição à aplicação dos princípios jurídicos. 17. ed. São Paulo: Malheiros, 2019.

BARCEllos, Ana Paula de. A Eficácia Jurídica dos Princípios Constitucionais - O princípio da dignidade da pessoa humana. 2. ed. Rio de Janeiro: Renovar, 2008.

BARROSO, Luís Roberto. Da falta de efetividade à judicialização excessiva: direito à saúde, fornecimento gratuito de medicamentos e parâmetros para a atuação judicial. Rio de Janeiro, 2007.

BRASIL. Constituição da República Federativa do Brasil: outorgada em 5 de outubro de 1988.

BRASIL. Emenda Constitucional n. 106, de 7 de maio de 2020. Institui regime extraordinário fiscal, 
financeiro e de contratações para enfrentamento de calamidade pública nacional decorrente de pandemia. Brasília, DF: Presidência da República, 2020.

BRASIL. Lei Complementar n. 173/2020, de 27 de maio de 2020. Estabelece o Programa Federativo de Enfrentamento ao Coronavírus SARS-CoV-2 (Covid-19), altera a Lei Complementar $n^{\circ} 101$, de 4 de maio de 2000, e dá outras providências. Brasília, DF: Presidência da República, 2020.

BRASIL. Lei Federal n. 13.979/2020, de 6 de fevereiro de 2020. Dispõe sobre as medidas para enfrentamento da emergência de saúde pública de importância internacional decorrente do coronavírus responsável pelo surto de 2019. Brasília, DF: Presidência da República, 2020.

BRASIL. Supremo Tribunal Federal. ADI no 6341 - MC-Ref. Relator: Marco Aurélio; Relator p/ Acórdão: Edson Fachin, 15 de abril de 2020. Tribunal Pleno. Diário de Justiça Eletrônico, Brasília, DF, n. 271, div. 12 nov. 2020, pub. 13 nov. 2020.

BRASIL. Supremo Tribunal Federal. ADPF n 672. Relator: Min. Alexandre de Moraes, 13 de outubro de 2020. Brasília: STF, 2020.

BRASIL. Supremo Tribunal Federal. Medida Cautelar na Ação Direta de Inconstitucionalidade (ADI) $n^{\circ}$ 6357. Relator: Min. Alexandre de Moraes, 29 de março de 2020. Brasília: STF, 2020.

BRASIL. Supremo Tribunal Federal. RCL n 42.637. Relator: Min. Alexandre de Moraes, 9 de setembro de 2020. Brasília: STF, 2020.

BRASIL. Supremo Tribunal Federal. Recurso Extraordinário 855178/RG. Relator: Min. Luiz Fux, 5 de março de 2015. Tribunal Pleno. Processo Eletrônico Repercussão Geral - Mérito. Diário de Justiça Eletrônico, Brasília, DF, n. 050, div. 13 mar. 2015, pub. 16 mar. 2015.

BRASIL. Superior Tribunal de Justiça. Suspensão de Liminar e de Sentença n 2794/ MT. 2020/02382391. Relator: Min. Humberto Martins, 21 de outubro de 2020. Decisão Monocrática. Brasília: STF, 2020.

BRASIL. Supremo Tribunal Federal. Suspensão de Tutela Provisória n 676/MG. Relator: Min. Luiz Fux, 21 de outubro de 2020. Brasília: STF, 2020.

CARDOSO, Ítala Lopes; CUNHA, Jarbas Ricardo Almeida. O mínimo existencial do direito à saúde no SUS: o caso do Programa Saúde da Família. Cadernos Ibero-Americanos de Direito Sanitário, Brasília, 5(4):9-26, out./dez, 2016.

CARVALHO, Délton Vinter. A natureza jurídica da pandemia da Covid-19 como um desastre biológico. Conjur, São Paulo, 21 abr. 2020. Disponível em: https://www.conjur.com.br/2020-abr-21/direito-posgraduacao-natureza-juridica-pandemia-covid-19-desastre-biologico. Acesso em: 20 jun. 2020.

FAGUNDES, Miguel Seabra. O Controle dos Atos Administrativos pelo Poder Judiciário. 5. ed. Rio de Janeiro: Forense, 1979.

GRAGNANI, Juliana. Por que o coronavírus mata mais as pessoas negras e pobres no Brasil e no mundo? BBC News Brasil, Londres, 12 jul. 2020. Disponível em: https://www.bbc.com/portuguese/ brasil-53338421. Acesso em: 18 nov. 2020.

PEREIRA, Jane Reis Gonçalves. Direitos sociais, estado de direito e desigualdade: reflexões sobre as 
críticas à judiciarização dos direitos prestacionais. Quaestio Juris, v. 8, n. 3, Rio de Janeiro, 2015.

RIO DE JANEIRO. Decreto Municipal $n^{\circ}$ 47.263, de 17 de março de 2020. Declara Situação de Emergência no Município do Rio de Janeiro, em face da pandemia do Co-ronavírus - Covid-19, e dá outras providências. Diário Oficial do Município do Rio de Janeiro: Ano XXXIV, Rio e Janeiro, RJ, p. 3, 18 mar. 2020.

SARLET, Ingo Wolfgang. A eficácia dos direitos fundamentais. Porto Alegre: Livraria do Advogado: 2001.

SARLET, Ingo W. A problemática dos direitos fundamentais sociais como limites materiais ao poder de reforma da constituição. In: SARLET, Ingo W. Direitos Fundamentais Sociais: Estudos de Direito Constitucional, Internacional e Comparado. Rio de Janeiro: Renovar, 2003.

SARLET, Ingo Wolfgang. Direitos fundamentais a prestações sociais e crise: algumas aproximações. Espaço Jurídico Journal of Law, Joaçaba, v. 16, n. 2, p. 459-488, jul./dez. 2015.

SARLET, Ingo Wolfgang. Os Direitos Fundamentais Sociais na Constituição de 1988. Revista Diálogo Jurídico, ano I, v. I, n. 1, Salvador, 2001.

SARLET, Ingo Wolfgang; FIGUEIREDO, Mariana Filchtiner. Algumas considerações sobre o direito fundamental à proteção e promoção da saúde aos 20 anos da Constituição Federal de 1988. Revista de Direito do Consumidor, n. 67, 2008.

SEN, Amartya. Desenvolvimento como liberdade. São Paulo: Companhia das Letras, 2000.

SENNETT, R. Construir e Habitar. Rio de Janeiro/São Paulo: Record, 2018.

TORRES, Ricardo Lobo. Tratado de Direito Constitucional Financeiro e Tributário. Os Direitos Humanos e a Tributação - imunidades e isonomia. Rio de Janeiro: Renovar, v. III, 1999.

UERJ. Pesquisa da Uerj revela influência das desigualdades sociais e crenças políticas na percepção sobre a Covid-19, Rio de Janeiro, UERJ, 2020. Disponível em: https://www.uerj.br/noticia/pesquisa-dauerj-revela-influencia-das-desigualdades-sociais-e-crencas-politicas-na-percepcao-sobre-a-covid-19/. Acesso em: 18 nov. 2020.

Recebido em: 30/11/2020

Aceito em: 17/12/2020 